\title{
De l'onction de Ps 89,21 à celle d'Is 61,1 (verbe חשי)
}

\author{
BERNARd GoSSE (ANTONY, FranCE)
}

\begin{abstract}
The characteristics of the covenant with David in Ps 89 are transferred to the patriarchs and their descendants in Ps 105 and Isa 41.1. Following up on the latter, especially Isa 42,1, one encounters the figure of the "servant" presented in Isa 42 as well as 49, in terms of the Mesopotamian year of liberation, when the servant receives the gift of the spirit. The title of מיח is also transferred to Cyrus in Isa 45,1, similarly from the perspective of the Mesopotamian year of liberation. The figure mentioned in Isa 61,1 appears like a disciple of the "servant," but he too receives an anointing, described with the verb משח, related to the gift of the spirit.
\end{abstract}

\section{RÉSUMÉ}

Les caractéristiques de l'alliance avec David du Ps 89 sont transférées sur les patriarches et leurs descendants dans le Ps 105 ou en Is 41,8. En continuité nous relevons la figure du "serviteur" présentée en Is 42 et 49, dans la mentalité de l'année Mésopotamienne de libération, et il reçoit le don de l'esprit. Mais le titre de משיח est transféré sur Cyrus en Is 45,1, également dans la perspective de l'année Mésopotamienne de libération. Le personnage d'Is 61,1 apparaît comme un disciple du « serviteur », mais il reçoit également une onction, verbe משח, liée au don de l'esprit.

KEYWORDS: Onction; Messie; Serviteur; Cyrus; Esprit; Psautier; Isaïe; Année de libération.

\section{A INTRODUCTION}

Dans le Psautier, le verbe מששח, n'apparaît que deux fois, en Ps 45,8 et 89,21. En Ps 45,8 il est fait référence à l'onction d'un roi idéal et en Ps 89,21 à l'onction de David. Dans les deux cas l'huile שמן, de l'onction est mentionnée. Dans le livre d'Isaïe le verbe משמח, n'apparaît qu'en Is 61,1, l'esprit רוח, se substituant à l'huile שמן, même si ce terme réapparaît en 61,3 dans l'expression l'« huile de la joie (שמן ששון) ». En lien avec le verbe, le substantif משיח, apparaît en Ps 2,2 ; 18,$51 ; 20,7 ; 28,8 ; 89,39.52 ; 132,10.17$ dans une perspective davidique ou de

* Submis: 14/07/2017; Evalué: 17/08/2017; accepté: 11/09/2017. Bernard Gosse, « De l'onction de Ps 89,21 à celle d'Is 61,1 (verbe משח), » Old Testament Essays 30 no. 3 (2017): 653-662. DOI: https://doi.org/10.17159/2312-3621/2017/v30n3a7 
réaffirmation messianique. En Ps 84,10 il s'agit, dans une perspective de substitution, du prêtre oint et en Ps 105,15, le titre est transféré aux descendants des patriarches. Dans le livre d'Isaie, le terme oint משיח, n'apparaît qu'une seule fois en Is 45,1, le titre étant attribué à Cyrus. Dans cette continuité l'onction d'Is 61,1 apparaît d'un type différent, mais nous allons voir qu'elle dérive aussi de l'onction davidique et plus particulièrement de la manière dont elle est présentée dans le Ps 89.

\section{B ALLIANCE ÉTERNELLE, ÉLECTION, SERVITEUR ET ONCTION EN PS 89,4 et 21}

En Ps 89,4: «J'ai fait (כרתי) une alliance (ברית) avec mon élu (לבירי) , j'ai juré à David mon serviteur (עבדי) », nous relevons la mention d'une alliance avec David. Dans la Bible une alliance avec David est mentionnée par ailleurs uniquement en $2 \mathrm{~S} 23,5$; Is 55,3 ; Jr 33,21; 2 Ch 13,$5 ; 21,7 .{ }^{1}$ Is 55,3 propose une alternative à l'alliance davidique et apparait donc postérieur. Le texte de $2 \mathrm{~S}$

1 Frank-Lothar Hossfeld et Erich Zenger, Psalms 2: A Commentary on Psalms 51 100 (Minneapolis: Fortress Press, 2005), 408. Ils notent que toutes les mentions de l'alliance avec David sont postexiliques. Gary. N. Knoppers, «Judah, Levi, David, Solomon, Jerusalem, and the Temple: Election and Covenant in Chronicles », in Covenant and Election in Exilic and Post-Exilic Judaism, éd. Nathan MacDonald, vol. 5 of Studies of the Sofja Kovalevskaja Research Group on Early Jewish Monotheism, (Tübingen : Mohr Siebeck, 2015), 155, relève que les Chroniques parlent d'alliance au sujet de l'« arrangement » avec David en s'alignant ainsi sur les Ps 89 et 132 (voir 132,12). Il n'en est pas de même dans les livres de Samuel et des Rois, à l'exception de $2 \mathrm{~S} \mathrm{23,5}$. Mais $2 \mathrm{~S} \mathrm{23,1-7}$ est étroitement relié à $2 \mathrm{~S} 22$ très proche du Ps 18, qui correspond à une réaffirmation davidique. En $2 \mathrm{~S} 23$ les liens avec la réaffirmation davidique des livres des Nombres (voir Nb 24,17), apparaît encore avec en $2 \mathrm{~S}$ 23,1 : נאם : נאם דוד בן־ישי ונאם הגבר הקם על בעם

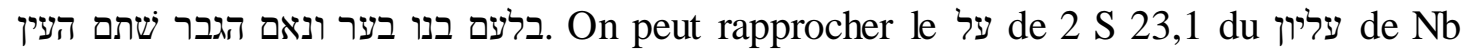

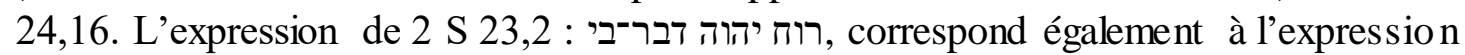
de Nb 24,2.3 : ותהי עלוי רוח אלהים וישא משלו ויאמר : Le 2 S 23,5 se retrouve en Nb 23,8.19.22.23; 24,4.8.16.23. Voir A. Graeme Auld, I \& II Samuel : A Commentary (Louisville: Westminter Knox Press, 2011), 594. Matthew J. Lynch, « The Davidic Covenant and Institutional Integration in Chronicles ", in Covenant and Election in Exilic and Post-Exilic Judaism, éd. Nathan MacDonald, vol. 5 of Studies of the Sofja Kovalevskaja Research Group on Early Jewish Monotheism, (Tübingen : Mohr Siebeck, 2015), 185, suggère que la réaffirmation de l'alliance avec la dynastie est liée à son rôle dans le culte. J'ai moi-même noté la relation étroite du rôle des lévites musiciens avec David et la dynastie dans les Chroniques (voir déjà $1 \mathrm{Ch} 15-16$ ). JeanLuc Vesco, Le Psautier de David (Paris : Cerf, 2006), 811, souligne que Ps 89,2-5 reprend le vocabulaire de 2 S 7, sauf que 2 S 7 ne parle pas d'alliance. Samuel Terrien, The Psalms : Strophic Structure and Theological Commentary (Grand Rapids: Eerdmans Publishing Company, 2003), 636, souligne le lien entre l'expression de $2 \mathrm{~S}$ 7,15: «Ma fidélité (וחסדי) ne s'écartera pas de lui », et l'usage de חסד en Ps 89,2.3.15.25.29.34.50. Mais le terme «alliance »n'est pas utilisé en 2 S 7. 
23,5 est étroitement lié à $2 \mathrm{~S} 22$ parallèle du Ps 18 . Les deux passages correspondent à une réaffirmation davidique et donc également à l'époque de la mention de l'alliance avec David. Le passage de Jr 33,21, correspond aussi à une réaffirmation davidique, en lien avec les lévites officiants dans le temple, et qui prétendaient avoir été mis en place par David. C'est également la perspective des livres des Chroniques auxquels appartiennent les attestations de 2 Ch 13,5 et 21,7. La réaffirmation de David et l'institution des chantres lévites dans le temple apparaît notamment en 1 Ch 16, en réponse aux Ps 96; 105,1-15 et 106, qui dans le Psautier transfèrent les caractéristiques de l'alliance avec David sur les patriarches. Il apparaît donc que le texte du Ps 89 est le premier à mentionner l'alliance de Yahvé avec David. Dans le Psautier le terme ברית apparaît précédemment en : Ps $25,10.14 ; 44,18 ; 50,5.16 ; 55,21 ; 74,20 ; 78,10-37$; $83,6 .^{2}$ En 83,6 il s'agit d'une alliance entre des ennemis. Ps 78,10.37, concerne une alliance avec les pères probablement deutéronomique, ${ }^{3}$ présentée comme un échec et conduisant à l'élection de David en Ps 78,70-72.Peut-être que l'alliance avec David a été conçue elle-même, dans un premier temps, comme un substitut à l'alliance défaillante avec les pères. Mais ensuite ce sera le contraire, la seule mention de Moïse dans le Psautier, en dehors des Ps 90-106, où l'on cherche des substituts à l'alliance avec David, se rencontre en Ps 77,21 qui fait de Moïse et Aaron des pasteurs, comme David à la fin du Ps 78. Dans un premier temps, Ps 89,4 : «J'ai fait une alliance (ברית) avec mon élu (לבחירי), j'ai juré à David mon serviteur (עבדי) », conçoit l'alliance avec David dans la continuité de Ps 78,70 : 《Il élut (עיבחר) David son serviteur (עבדו), il le tira des parcs à moutons ». C'est le seul usage de עבד dans le Ps 78. Quant aux deux autres usages du verbe בחדר לאר ל ils préparent en fait celui de Ps 78,70. Nous relevons לא בחר en Ps 78,67, au sujet de la tribu d'Efraïm et ויבחר Ps 78:68 au sujet de la tribu de Juda. ${ }^{4}$ La

2 William H. Bellinger Jr., «The Psalms, Covenant, and the Persian Period », in Covenant in the Persian Period from Genesis to Chronicles, éd. Richard J. Bautch et Gary N. Knoppers (Winona Lake: Eisenbrauns, 2015), 312 (Ps 74,19-20): «The Covenant here is most likely tied to the Sinaitic expression of covenant with an emphasis on the divine responsibility in that relationship .... The Sinaitic / Mosaic covenant tradition characterizes the deity as the one who comes to deliver, to initiate or to renew a relationship ». Il assimile ensuite le Ps 79 au Ps 74. Ensuite il relève p. 315 (Ps 44): «That confession of faithfulness is specified further in v. 21 (20) with the affirmation that the community has not forgotten God or prayed "to a strange god". The affirmation of the psalm alludes to the first commandment of the Decalogue and thus to covenant keeping. The community has kept covenant. The reference is clearly to the Sinaitic Covenant tradition ».

3 Hossfeld et Zenger, Psalms 2, 297: « here in vv. 36-37 a new tone sounds in the scene, for lies and breaking the covenant indicate a covenantal relationship that seems to presume the Deuteronomistic establishing of the covenant in Exod 24:3, 7-8 ».

4 Hossfeld et Zenger, Psalms 2, 299: «because Judah becomes the heir of or substitute for the Northern Kingdom, which vanishes from the history of Israel. Judah, Zion and David are the enduring constants of the election ». 
conception de l'alliance du Ps 89 avec David apparaît donc bien dans la continuité de la fin du Ps 78, qui a constaté précédemment l'échec de l'alliance antérieure, probablement deutéronomique. D'autant plus que Ps 89,29.37-38:

29 A jamais je lui garde mon amour, mon alliance est pour lui véridique (ובריתי נאמנת לו). 37 Sa lignée à jamais sera, et son trône comme le soleil devant moi, 38 comme est fondée la lune à jamais, témoin véridique (נאמן) dans la nue,

au sujet de l'alliance avec David apparait, par l'action divine, comme répondant aux imperfections de l'alliance de Ps 78,8.37:

8 qu'ils ne soient pas, à l'exemple de leurs pères, une génération de révolte et de bravade, génération qui n'a point le cœur sûr et dont l'esprit n'est point fidèle (ולא נאמנה) à Dieu. 37 leur coeur n'était pas sûr envers lui, ils étaient sans foi en son alliance (ולא נאמנו בבריתו).

La mention de l'onction apparaît en Ps 89,21: «j'ai trouvé (מצאת (מבדי) David

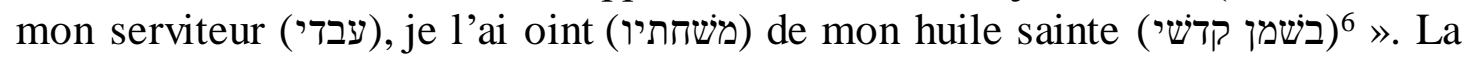
mention du serviteur עבד, renvoie à Ps 89,4, avec la confirmation du lien entre l'onction et l'alliance en Ps 89,39-40 : «39 Mais toi, tu as rejeté et répudié, tu t'es emporté contre ton oint (משיחך) ; 40 tu as renié l'alliance de ton serviteur (ברית עבדך), tu as profané jusqu'à terre son diadème ». Dans le Psautier le verbe משח, n'apparait qu'une seule autre fois en 45,8 , au sujet d'un roi, avec la mention de l'huile d'allégresse שמן ששון. Mais en référence à David on peut penser à $1 \mathrm{~S}$ 16,13a : «Samuel prit la corne d'huile (השמן) et l'oignit (וימשה) au milieu de ses frères.» Les relations entre le Psautier et les livres de Samuel seront accentuées ultérieurement par des titres de psaumes qui renvoient à des passages des livres de Samuel en raison d'accrochages verbaux. Les deux emplois de משיח en Ps 89,39.51, concernent le rejet du messie, et ce point ne peut se comprendre qu'en rapport à la rédaction d'ensemble du Psautier qui va envisager diverses solutions. ${ }^{7}$ Le terme משיח, apparaît 18 fois dans les livres de Samuel et 10 fois dans le Psautier, les attestations du lévitique concerne un prêtre, celles des Chroniques correspondent à des reprises du Psautier, en Is 45,1 il s'agit de Cyrus, en $\operatorname{Lm~4,20~de~Sédécias,~en~Dn~9,25~on~peut~penser~à~Cyrus~}{ }^{8}$ et en 9,26 au grand

5 אמן (niphal) : Ps 19,8; 78,8.37 : 89,29.38;93,5; 101,6; 111,7, dans le Psautier.

6 Hossfeld et Zenger, Psalms 2, 410: «Unlike the model in 1 Samuel 16, here in v. 21 'holy oil' is used for the anointing, something characteristic of anointing's in the Priestly tradition (cf. Exod 30:25; 37:29; Num 35:25) ».

7 Bernard Gosse, L'espérance messianique davidique et la structuration du Psautier (Pendé : Gabalda, 2015).

8 Carol A. Newsom with Brennan W. Breed, Daniel (Louisville: Westminter John Knox Press, 2014), 304 (Dn 9:25): « The first period of time is measured as seven weeks, which is to say, the time of a Jubilee. Clearly this designation is important. It defines the time from the beginning of the exile to the return after the decree of Cyrus ». De ce point de vue, Dn 9,25 se situe dans la continuité d'Is 45,1. 
prêtre Onias III $^{9}$. En Hab 3,13 on peut supposer ne serait-ce que par le parallélisme, qu'il s'agit du peuple. ${ }^{10}$ Le terme משיח, pour désigner David et ses descendants apparaît donc comme une caractéristique commune du Psautier et des livres de Samuel. Dans le Psautier le terme peut désigner le prêtre en Ps 89,10 , ou la descendance des patriarches comme en Ps 105,15, en fonction de l'approche de la question messianique, suite à l'exil.

\section{LE TRANSFERT DES CARACTÉRISTIQUES DE L'ALLIANCE DAVIDIQUE SUR LES PATRIARCHES ET LEUR DESCENDANCE EN PS 105,6.8-9.15}

La transposition des titres de serviteur (עבד) et élu (בחיר), de David et sa descendance sur celle des patriarches et leur descendance, apparaît en Ps 105,6 : «Lignée (זרע) d'Abraham son serviteur (עבדו), enfants (בני) עביר) de Jacob ses élus

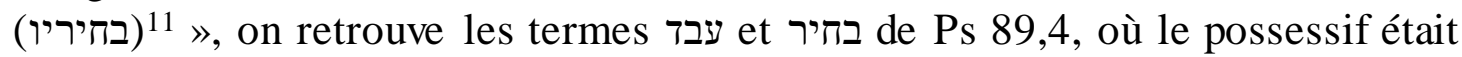
« moi ». Le terme זרע est également utilisé en Ps 89,5.30.37, avec un possessif renvoyant à David. Le terme בן est également utilisé en rapport à David en Ps 89:31.

En Ps 105,8-9 : «8 Il se rappelle à jamais son alliance (בריתו), parole promulguée pour mille (לאלף) génération, 9 pacte conclu (כרת) avec Abraham, serment qu'il fit à Isaac », on retrouve la mention de l'alliance (ברת) conclu (כרת), comme dans le cas de David. La mention de mille (אלף) générations, reprend en l'amplifiant à Ps 90,4 : «Car mille (אלף) ans sont à tes yeux comme le jour d'hier qui passe, comme une veille dans la nuit », qui cherchait une première réponse au constat du Ps 89 quant au rejet du messie davidique.

En Ps 105,15 : «Ne touchez pas à mes oints (במשיחי), à mes prophètes ne faites pas de mal », nous relevons le transfert du terme מלנביאי) (ולניח la descendance des patriarches. Ce verset répond également à la question portant sur la disparition des prophètes selon Ps 74,9.12

9 Newsom with Breed, Daniel, 306: «The anointed one who is cut off is almost certainly to be identified as the high priest Onias III ».

10 Brian Tidiman, Nahoum Habaquq Sophonie (Vaux-sur-Seine : Edifac, 2009), 222 : «Il soutient, à cette fin, son messie, associé au "peuple" par le parallélisme du verset dans la mesure où il désigne un chef donné au peuple par Dieu... ».

11 Hans-Joachim Kraus, Psalms 60-150 (Minneapolis: Augsburg, 1989), 310: «In v.6 the address to Israel (זרע אברהם בני יעקב) already leads over the main theme. For there the subject will be the faithfulness of Yaweh, who has fulfilled the covenant and the prophecy made to the patriarchs. But all this applies directly to the present generation as the "seed of Abraham". »

12 Kraus, Psalms 60-150, 311: «Therefore how is the appearance of the term משיח v. 15 to be explained? Is this an allusion to the anointing of the (cf. 1 Kings 19:16; Isa. 61:1)? Or is this a matter of transferring the ("democratized") title of king to the patriarch (cf. Exod. 19:6; Isa. 61:6)? In any case, the term משיח emphasizes the 
658 Gosse, “De l'onction de Ps 89,21," OTE 30/3 (2017): 653-662

\section{CONTINUITÉ DU TRANSFERT DES TITRES DAVIDIQUES SUR LES PATRIARCHES ET LEUR DESCENDANCE EN IS 41,8}

Le transfert des caractéristiques de l'alliance davidique sur les patriarches et leur descendance est confirmé en Is 41,8 : «Et toi, Israël, mon serviteur (עבדי), Jacob que j'ai choisi (בחרתיך), race d'Abraham mon ami », on relève la continuité de transfert au profit des patriarches et de leur descendance du titre de «serviteur (עבד) » et de la mention de l'élection (verbe בחר).

\section{E LE «SERVITEUR » ET «ÉLU » EN ISA 42,1.6, ET LE MESSIE CYRUS EN IS 45,1, DANS LA PERSPECTIVE CONJOINTE DE L'ANNÉE DE LIBÉRATION MÉSOPOTAMIENNE}

En Is 42,1 : «Voici mon serviteur (עבדי) que je soutiens, mon élu (נרתי) en qui

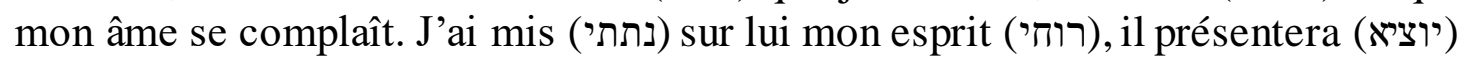
aux nations le droit (משפט) 》, nous retrouvons le transfert des titres de mon serviteur (בבדי) et mon élu (בחירי). La mention du don de mon esprit (רוחי), apparaît comme une nouveauté. Nous allons voir qu'il s'agit d'une substitution par rapport à l'onction du messie. Le don de l'esprit au serviteur apparait comme une alternative au don de l'esprit sur le descendant de Jessé en Is 11,2 :

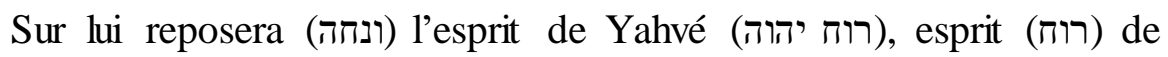

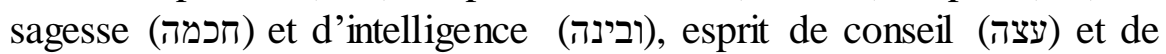
force (וגבורה), esprit de connaissance (דעת) et de crainte de Yahvé (ויראת יהוה).

Le vocabulaire très sapientiel correspond à la promesse de Prov 1,23 : «Convertissez-vous à mon exhortation, pour vous je vais répandre (אביעה) mon esprit (רוחי) et vous faire connaître mes paroles ». La référence à l'onction messianique se trouve elle transférée sur Cyrus en Is 45,1: «Ainsi parle Yahvé à son oint (למשיחו), à Cyrus ${ }^{15}$ dont j'ai saisi la main droite, pour faire plier devant

inviolability and unassailability of the "anointed one" (cf. 2 Sam. 1:14f) ». FrankLothar Hossfeld et Erich Zenger, Psalms 3: A Commentary on Psalms 101-150 (Minneapolis: Fortress Press, 2011), 71, renvoie à Gn 20,7 (נביא) et Ps 47,10 au sujet du statut d'Abraham vis-à-vis des princes («boucliers » enduits de graisse).

13 Klaus Baltzer, Deutero-Isaiah (Minneapolis: Fortress Press, 2001), 100 (Is 41,8.9a): "But Ps 105:6 explicitly calls Jacob "the chosen one" (בחיר), and parallel to this is the description of Abraham as "servant" (עבדו; cf. v. 42). The psalm is especially interesting because it links the early traditions with the present in a similar way to the passage we are considering ».

14 John Goldingay, The Message of Isaiah 40-55 (New York: T\&T Clark, 2005), 155: «Such links suggest that $42.1 \mathrm{~b}$ relates directly to $11.1-5 \ldots$ The Davidic hope is again democratized ».

15 Goldingay, Isaiah 40-55, 263: «Yet Cyrus is the other side of the coin fear the Assyrian King. He was Yhwh's agent in troubling Israel, the Persian king is restoring it $\gg$. 
lui les nations et désarmer les rois, pour ouvrir devant lui les vantaux, pour que les portes ne soient plus fermées ». En Is 42,6 le serviteur est également présenté comme une alliance : «Moi, Yahvé, je t'ai appelé dans la justice, je t'ai saisi par la main, et je t'ai modelé, j'ai fait de toi l'alliance du peuple (לברית עם), la lumière des nations ». Cette alliance est comme celle des patriarches, valable pour tous leurs descendants, c'est-à-dire le peuple et non seulement la dynastie davidique. Le rôle du serviteur, mais également de Cyrus se comprend bien dans la perspective de l' «année de grâce mésopotamienne », qui correspondait à un retour des terres à leurs propriétaires et à une libération des esclaves. ${ }^{16}$ En ce qui concerne le « serviteur », on peut noter qu'Is 42,4a: «Il ne faiblira ni ne cédera jusqu'à ce qu'il établisse le droit sur la terre (עד ישים בארץ משפט) 》, correspond à la thématique akkadienne de l'année de grâce, avec l'expression akkadienne : « pour établir l'équité sur la terre (mišaram ina matim šakanum) ». ${ }^{17}$ Le rôle de Cyrus pouvait donc également apparaître dans cette ligne. On comprend qu'une partie de la perspective de libération lui ait été attribuée, d'autant plus qu'il était lui-même un souverain mésopotamien. De plus, en tant que roi, on pouvait donc lui transférer le titre de משיח, lié à l'onction.

\section{F LE DON DE L'ESPRIT ET L'ALLIANCE EN IS 59,21}

La pérennité de l'alliance, comme don de l'esprit, à un disciple du « serviteur », est mentionnée en Is 59,21:

Et moi, voici mon alliance (בריתי) avec eux, dit Yahvé : mon esprit (רוחי) qui est sur toi et mes paroles que j'ai mises dans ta bouche ne s'éloigneront pas de ta bouche, ni de la bouche de ta descendance, ni de la bouche de la descendance de ta descendance, dit Yahvé, dès maintenant et à jamais. ${ }^{18}$

L'alliance est liée au don de l'esprit et est en faveur du peuple.

16 Moshe Weinfeld, Social Justice in Ancient Israel and in the Ancient Near East (Jerusalem: The Magnes Press / Minneapolis: Fortress Press, 1995), 95: « Thus we see that the liberation year, when land reverted to its original owner and slaves returned home, was an institution in Mesopotamia from the old-Babylonian period... According to 2 Kings 25:27, Ewil Merodach king of Babylon freed Jehohiachim king of Judah from prison upon his ascent to the throne. This was undoubtedly a part of the liberation and amnesty proclaimed by Evil Merodach at his coronation ».

17 Weinfeld, Social Justice, 45-46.

18 John Goldingay, Isaiah 56-66 (London: Bloomsbury, 2014), 235: « The words recall those in earlier and later passages in which the prophet speaks $(48.16 \mathrm{~b} ; 50.4$; 61.1) and passages that speak about Yhwh's servant and could plausibly be applied to the position of a prophet $(42.1 ; 53.10) »$. 
660 Gosse, “De l'onction de Ps 89,21," OTE 30/3 (2017): 653-662

\section{G LE DON DE L'ESPRIT COMME ONCTION (VERBE משיחה) EN IS 61,1-2aa}

Le texte d'Is 61,1.2a , présente le don de l'esprit à un personnage particulier dans la continuité d'Is 42,1 et 59,21. ${ }^{19}$ Mais la nouveauté est que la thématique de l'onction est réintégrée en rapport au don de l'esprit de Yahvé avec usage du verbe משחה. On relève :

1 L'esprit (רוח) du Seigneur Yahvé est sur moi, car Yahvé m'a donné l'onction (משחה) ; il m'a envoyé porter la nouvelle aux pauvres, panser les cœurs meurtris, annoncer aux captifs (ולאסורים) la libération (דרור) (T) $^{20}$ et aux prisonniers la délivrance 2 proclamer une année de grâce (רצון) de la part de Yahvé.

Cette réintégration du thème de l'onction se fait dans le cadre de la proclamation d'une «année de grâce de la part de Yahvé » (Is 61,2). Dans la continuité de la tradition mésopotamienne, cette perspective était déjà présente en Is 42,1-7. ${ }^{21}$ Il s'agissait notamment d'une "libération », perspective dans laquelle pouvait être également situé Cyrus. Cette perspective de «libération» et de rétablissement de l'ordre originel se situe également dans la continuité d'Is 49,5-10, autre texte du « serviteur ». ${ }^{22}$ On peut relever particulièrement Is 49,8$9 \mathrm{a} \alpha$ :

8 Ainsi parle Yahvé : Au temps de la faveur (בעת רצון (בעון ${ }^{23}$ je t'ai exaucé, au jour du salut je t'ai secouru. Je t'ai façonné et j'ai fait de toi l'alliance (לברית) d'un peuple pour relever le pays, pour restituer les héritages dévastés, 9 pour dire aux captifs (לאסורים) : "Sortez", à ceux qui sont dans les ténèbres : "Montrez-vous".

19 Goldingay, Isaiah 56-66, 295: «The opening claim that 'the breath of my Lord Yhwh is on me' takes up words that related to the prophet in 59.21 but go back behind that passage to words concerning Yhwh's servant in 42,1 '[I have put] my breath on him'. »

20 Voir Lv 25,10 qui reprend la tradition mésopotamienne de l'année de la libération.

21 Weinfeld, Social Justice, 45, n. 3: « The redeemer in Isa 42:1-7 is very similar to the liberator in Isa. 61:1-3, cf. also 49:9, the continuation of the Servant song which begins at 49:1. »

22 Goldingay, Isaiah 40-56, 376 (Is 49,8) : « The phrase 'a time of acceptance' (רצון) recurs in Ps. 69.13[14]; Isa 58.5 has 'a day of acceptance' 61.2 'a year of acceptance'. » Is 58 est également à comprendre dans la perspective de l'année de la libération. Du reste la Septante mêle à sa traduction d'Is $61,1-2$ un passage d'Is 58,6 .

23 : Is 4,$8 ; 56,7 ; 58,5 ; 60,7.10 ; 61,2$

24 אסר part paül Is 49,9 ; 61,1 ; autre emploi du verbe dans le livre d'Isaïe au pual en Is 22,3 . 


\section{H CONCLUSION}

Dans le Ps 105, les titres davidiques du Ps 89 se trouvent transférés sur la descendance des patriarches. Cet aspect est intégré par le livre d'Isaïe en 41,8, mais avec un nouveau transfert sur le « serviteur » et « élu » en Is 42,1, dans la perspective de l'année de libération mésopotamienne. Le don de l'esprit est également mentionné. Par contre l'onction se trouve transférée sur Cyrus en Is 45,1, parfait représentant pour l'année de libération mésopotamienne. Le personnage d'Is 61,1 se situe dans la continuité du serviteur, mais de plus il réintègre à sa manière le don de l'onction, avec l'usage du verbe משח, qui s'applique cette fois au don de l'esprit.

\section{BIBLIOGRAPHIE}

Auld, A. Graeme. I \& II Samuel: A Commentary. Louisville: Westminter Knox Press, 2011.

Baltzer, Klaus. Deutero-Isaiah. Minneapolis: Fortress Press, 2001.

Bellinger, William H. Jr. «The Psalms, Covenant, and the Persian Period ». Pages 309-322 dans Covenant in the Persian Period From Genesis to Chronicles.

Edité par Richard J. Bautch et Gary N. Knoppers. Winona Lake: Eisenbrauns, 2015.

Goldingay, John. The Message of Isaiah 40-55. New York: T\&T Clark, 2005. . Isaiah 56-66. London: Bloomsbury, 2014.

Gosse, Bernard. L'espérance messianique davidique et la structuration du Psautier. Pendé: Gabalda, 2015.

Hossfeld, Frank-Lothar et Erich Zenger. Psalms 2: A Commentary on Psalms 51-100. Minneapolis: Fortress Press, 2005.

. Psalms 3: A Commentary on Psalms 101-150. Minneapolis: Fortress Press, 2011.

Knoppers, Gary N. «Judah, Levi, David, Solomon, Jerusalem, and the Temple: Election and Covenant in Chronicles ». Pages 139-168 dans Covenant and Election in Exilic and Post-Exilic Judaism. Edited by Nathan MacDonald. Vol. 5 of Studies of the Sofja Kovalevskaja Research Group on Early Jewish Monotheism. Tübingen : Mohr Siebeck, 2015.

Kraus, Hans-Joachim. Psalms 60-150. Minneapolis: Augsburg, 1989.

Lynch, Matthew J. « The Davidic Covenant and Institutional Integration in Chronicles ». Pages 169-188 dans Covenant and Election in Exilic and PostExilic Judaism. Edited by Nathan MacDonald. Vol. 5 of Studies of the Sofja Kovalevskaja Research Group on Early Jewish Monotheism. Tübingen : Mohr Siebeck, 2015.

Newsom, Carol A. with Brennan W. Breed. Daniel. Louisville: Westminter John Knox Press, 2014.

Terrien, Samuel. The Psalms. Strophic Structure and Theological Commentary. Grand Rapids: Eerdmans Publishing Company, 2003.

Tidiman, Brian. Nahoum Habaquq Sophonie. Vaux-sur-Seine : Edifac, 2009.

Vesco, Jean-Luc. Le Psautier de David. Paris : Cerf, 2006. 
662 Gosse, “De 1'onction de Ps 89,21," OTE 30/3 (2017): 653-662

Weinfeld, Moshe. Social Justice in Ancient Israel and in the Ancient Near East. Jerusalem: The Magness Press / Minneapolis: Fortress Press, 1995.

Bernard Gosse, Antony, France. Email: gosse.bernard.old@orange.fr. 